GESINSPOLITIEK EN DIE OUER-KIND VERHOUDING

ISSN 1727-3781

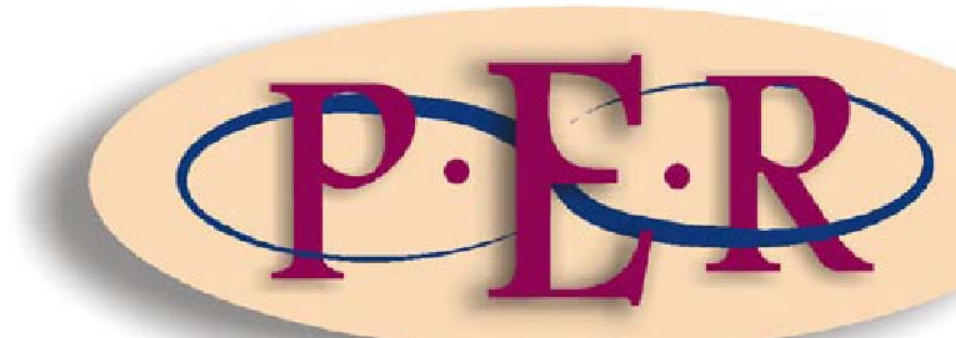

1998 VOLUME 1 No 1 


\section{GESINSPOLITIEK EN DIE OUER-KIND VERHOUDING}

C Maré

\section{INHOUDSOPGAWE}

1 Inleiding

2 Posisie voor die 1993 Grondwet

2.1 Inleiding

2.2 Die gemeenregtelike ouer-kind verhouding

2.3 Gewoonteregtelike gesinstrukture

2.4 Gevolgtrekking

3 Posisie na die 1993 Grondwet en die 1996 Grondwet

3.1 Inleiding

3.2 Gewoontereg en die Grondwette

3.3 Grondwetlike beskerming verleen aan kinders

3.4 Gevolgtrekking 4

Samevatting

Families can be islands of support and comfort; families can also be arenas of conflict and abuse.

- Martha Minow -

\section{Inleiding}

Dat die era van die nuwe Suid-Afrika met 'n veranderde grondwet betree is, is al 'n cliché in die algemene omgangstaal. Wat egter nog onseker is, is hoe die Grondwet van die Republiek van Suid-Afrika 200 van $1993^{1}$ en die Grondwet van die Republiek van SuidAfrika 108 van $1996^{2}$ die verskillende aspekte van die gevestigde gemeenskaplewe raak. Die vraag ontstaan dus nou wat die implikasies van die twee grondwette se hoofstukke oor fundamentele regte vir die ouer-kind verhouding inhou.

1 Hierna genoem 1993 Grondwet.

2 Hierna genoem 1996 Grondwet. 
Die verhouding tussen ouer en kind word nie in die Suid-Afrikaanse reg bevredigend gereël nie. Die tipering van hierdie verhouding in terme van ouerlike gesag is uitgedien. Tans beskik Suid-Afrika oor grondwetlike beskerming van fundamentele regte wat die publiekregtelike verhouding in Suid-Afrika reguleer. Die aanvaarding en implementering van hierdie nuwe grondwetlike stelsel sal wesenlike wysigings aan die huidige SuidAfrikaanse familiereg noodsaak. ${ }^{3}$ Die doel van hierdie bespreking is om ' $n$ positiefregtelike perspektief op die ouer-kind verhouding in die Suid-Afrikaanse reg weer te gee en die moontlike implikasies van die hoofstukke oor fundamentele regte in die twee grondwette op die besluitnemingsproses aanwesig binne die ouer-kind verhouding te bespreek.

Die kind en die ouer se individuele belange kan in konflik kom waar daar besluite geneem moet word aangaande verskeie vraagstukke soos byvoorbeeld watter kerk die kind moet bywoon en of sy enigsins 'n kerk wil bywoon; by watter skool 'n kind ingeskryf moet word; met wie die kind mag assosieer en met wie nie; of die kind voorbehoedmiddels mag gebruik en of 'n adolessente meisie uit eie keuse 'n aborsie mag weier of versoek. Sodanige probleemsituasies kan die besluitnemingsproses in die ouer-kind verhouding aktiveer en 'n stelsel van gesinspolitiek implementeer. Voorts moet dit ook in gedagte gehou word dat die besluitnemingsproses eiesoortig is aan elke ouer-kind verhouding. Verskillende sosiale, ekonomiese en kulturele faktore aanwesig in die gemeenskap waarin die ouer-kind verhouding sentraal staan, beïnvloed die hantering van konflik in die besluitnemingsproses. Implikasies van die hoofstukke oor fundamentele regte in die twee grondwette op die besluitnemingsproses kan byvoorbeeld verskil waar konflik enersyds in die gemeenregtelike ${ }^{4}$ ouer-kind verhouding en andersyds in 'n gewoonteregtelike ${ }^{5}$ ouerkind verhouding ontstaan ' $n$ Belangrike oorweging in hierdie verband is die versoenbaarheid van die gewoontereg met die grondwette, want die grondslag van fundamentele regte is geleë in die erkenning van individue se regte terwyl die grondslag van die gewoontereg,

3 A 39(3) van die 1996 Grondwet bepaal dat by die uitleg van enige wet en die toepassing en ontwikkeling van die gemenereg en gewoontereg, 'n hof die gees, strekking en oogmerke van die hoofstuk oor fundamentele regte behoorlik in ag moet neem.

4 Dws die Romeins-Hollands-gefundeerde reg. 
5 Dws die reg mbt die tradisionele Afrika-gemeenskap. 
kommunalisme ${ }^{6}$ is.

Alvorens die omvang en inhoud van die Suid-Afrikaanse ouer-kind verhouding bespreek kan word, moet daar egter eers duidelik begryp word wat met die terme familie en gesin in die Suid-Afrikaanse familiereg bedoel word. Die begrip familie word in die wye en in die eng $\sin$ in die familieregliteratuur aangetref. In die wye sin sluit dié begrip alle persone in wat bloedverwant of op grond van 'n huwelik aan mekaar verwant is. In die eng sin van die woord is 'n familie 'n gesin wat bestaan uit 'n man, sy vrou en kinders. Stelselmatig is die konsep van die familie-eenheid vervang met die konsep van die gesinseenheid. In die SuidAfrikaanse familieregliteratuur word die volgende twee terme aangetref wanneer skrywers na die gesin verwys, naamlik die uitgebreide gesin (extended family) ${ }^{7}$ en die kerngesin (nuclear family). ${ }^{8} \quad$ Die uitgebreide gesin is meer algemeen teenwoordig in die SuidAfrikaanse gemeenskap waar gewoonteregtelike strukture aangetref word. Dit moet baie duidelik gestel word dat die Suid-Afrikaanse familiereg eers teen die einde van die twintigste eeu ander gesinne as die bogenoemde twee vorme in die gemeenskap erken het. $^{9}$

'n Wetenskaplike bespreking van die verhouding tussen ouer en kind veronderstel ' $n$ voorafgaande kennisneming van die geskiedenis onderliggend aan hierdie verhouding. Kennis moet geneem word van die historiese herkoms en ontwikkeling

6 Sien 3.2 hieronder vir ' $\mathrm{n}$ bespreking van die wisselwerking tussen die gewoontereg en die grondwette. 7 Met dié gesinstipe word volgens McQuoid-Mason D Street Law: Practical Law of South African

Students Vol 4 (Kaapstad 1990) 1 die volgende bedoel: Before the development of large towns and cities in South Africa most people lived in the country in 'extended families'. This means that children, their parents, and sometimes grandparents all lived together in one home or in small communities on farms or in small villages. As a result extended families consisted of grandparents, uncles and aunts, brothers and sisters, nieces and nephews, children and even cousins.

8 Met hierdie gesinstipe word volgens McQuoid-Mason Street Law 1 die volgende bedoel: During the twentieth century when there was a move away from the country into the cities, many extended family units were broken up, ... people began to form individual 'nuclear families'. A nuclear family is one where just the parents and their children live together without other relatives.

9 Die feit dat die Suid-Afrikaanse gesin op ' $n$ hoë vlak van veralgemening as ' $n$ klein verwantskap gestruktureerde groep gedefinieer is, laat toe dat daar op 'n meer konkrete en gespesifiseerde vlak na verskillende gesinstipes gekyk kan word. Ander gesinstipes wat in die Suid-Afrikaanse familiereg voorkom is onder andere die enkel-ouer gesin, die poligamiese gesin en die sosiale gesin. 
van die familie binne 'n bepaalde sosiale konteks, anders is sodanige bespreking ankerloos. $^{10}$ Dit is belangrik om daarop te let dat die aard van die ouer-kind verhouding nie neutraal is nie, maar deur historiese en sosiale elemente in die gemeenskap bepaal word. Heelwat van die kenmerke van die Suid-Afrikaanse reg ten aansien van die ouer-kind verhouding kan verklaar word met verwysing na die oorsprong en herkoms daarvan.

\section{Posisie voor die 1993 Grondwet}

\subsection{Inleiding}

Die familie-eenheid het in die een of ander vorm voorgekom sedert die begin van die mens se bestaan. Die doel van dié eenheid was om kinders te verwek en te versorg tot volwassenheid. Die versorging het fisies sowel as geestelike en emosionele versorging behels. Om hierdie versorgingsdoel te verwesentlik, is 'n besluitnemingsproses vereis. Tradisioneel beskou, was die vader gesien as die gesagdraende party in die eenheid en het hy die besluitnemingsproses geïnisieer. ${ }^{11}$ Sy gesag is as absoluut beskou. Wanneer daar dan konflik tussen die individuele lede van die familie-eenheid ontstaan het aangaande die besluitnemingsproses, is die probleem opgelos deur die absolute reg van die vader te laat seëvier bo dié van die kind. Die moeder se aandeel in die besluitnemingsproses is ontken deur die familiehoof, naamlik die vader. Regsontwikkeling tot en met die agtiende eeu het tot gevolg gehad dat vanuit die absolute reg van die vader oor sy kinders 'n leerstuk van ouerlike reg (met ouerlike gesag as fondament) in die familieeenhied wortel geskiet het. Sedert die aanvang van die twintigste eeu egter het 'n afwatering van die ouerlike regte-leerstuk plaasgevind. Die afwatering was die gevolg van die meerderheidsiening dat ouers nie oor absolute beheer en kontrole beskik ten aansien van 'n kind se opvoeding en versorging totdat volwassenheid intree nie.

10 Sien, in die algemeen, Maré C Gesinspolitiek 1-44 vir 'n regshistoriese perspektief op die ontwikkeling van die ouer-kind verhouding in die Suid-Afrikaanse familiereg vanaf die oorsprong daarvan in die Romeinse reg, deur die Middeleeue heen, tot by die resepsie van die RomeinsHollandse reg in die Suid-Afrikaanse reg. 
Dit is gemeensaak dat sosio-ekonomiese en politieke veranderinge wat deur die eeue ingetree het, 'n onvermydelike verandering vir die Suid-Afrikaanse ouer-kind verhouding teweeggebring het. Ter verduideliking kan genoem word dat die Suid-Afrikaanse gemeenskap teen die einde van die 18e eeu reeds "pluraal" of multikultureel van aard was. Die gemeenskap was saamgestel uit Nederlandse en Duitse setlaars en Franse hugenote asook inheemse bevolkingsgroepe. Dit het die ingrypende gevolg gehad dat die RomeinsHollandse regstelsel, die Nederlandse taal en die gereformeerde geloof die funksionering van die multikulturele gemeenskap en die besluitnemingsproses in die ouer-kind verhouding, bepaal het.

Sedert die dertigerjare het die Suid-Afrikaanse regstelsel 'n dualistiese of pluralistiese karakter ontwikkel. Die rede vir die ontwikkeling hiervan was die implementering van 'n nuwe politieke filosofie bekend as afsonderlike ontwikkeling of apartheid. Nhlapo verwoord die invloed van die dualistiese karakter van die Suid-Afrikaanse regstelsel op die familiereg soos volg:

(T)here now exists an ever-increasing gap between the idealised 'traditional' family and contemporary reality. Family law sits uneasy between the two: should it mirror reality or promote a particular view of social ordering? Posed in this way, the question is virtually unanswerable but in practice, ..., family law has often been called upon to do both at particular moments in history.

Dit is belangrik om daarop te let dat daar in die Suid-Afrikaanse familiereg voor 1993 onderskeid gemaak is tussen gemeenregtelike en gewoonteregtelike gesinstrukture. Eersgenoemde is gereël deur die gemenereg en laasgenoemde deur sowel die gemenereg as die gewoontereg.

11 Maré C Gesinspolitiek 3-4. Dit is belangrik om in gedagte te hou dat die vader die gesagdraende party in sowel die gewoonteregtelike as die gemeenregtelike familie-eenheid was. 
12 Dié dualistiese karakter het vir die volgende vyftig jaar 'n invloed gehad op elke aspek van die SuidAfrikaanse gemeenskap en was duidelik sigbaar in die familiereg.

13 Nhlapo Future of Family Law 13. 


\subsection{Die gemeenregtelike ouer-kind verhouding}

Die kerngesin (nuclear-family) is tradisioneel beskou as ' $n$ gesin wat bestaan uit ' $n$ werkende vader, ' $n$ tuisteskeppende moeder en nie meer as twee afhanklike kinders nie. McQuoid-Mason identifiseer egter 'n aantal faktore wat die inhoud en omvang van die gesinstipe verander het:

Many married women now go out to work and many couples in the cities and towns have fewer children or no children at all. Increases in the number of illegitimate children and divorces have created a large number of 'single parent' families. Alternative life styles, like people living together in one home as a small community are becoming more common. ${ }^{14}$

'n Tendens wat egter nie verander het nie, is die feit dat die gesin steeds die basiese eenheid in die gemeenskap is, maar daar is tans soveel verskillende tipes gesinne aanwesig dat dit moeilik is om 'n tipiese gesin te definieer. Vir doeleindes van hierdie bespreking van die gemeenregtelike ouer-kind verhouding, word aanvaar dat dié verhouding kan bestaan uit twee ouers van die teenoorgestelde geslag en ('n) kind/ers, óf uit twee ouers van dieselfde geslag en ('n) kind/ers, óf uit een ouer (hetsy manlik of vroulik) en ('n) kind/ers.

Dat daar nie ooreenstemming bestaan in die Suid-Afrikaanse familiereg oor die aard

14 McQuoid-Mason Street Law 2.

15 In Van Rooyen $v$ Van Rooyen 19942 SA 325 (W) het regter Flemming die toegangsregte van die applikant tot haar twee minderjarige kinders aan swaar voorwaardes gekoppel, aangesien sy betrokke was in 'n lesbiese verhouding en die gangbare moraliteit (volgens hom) lesbiese verhoudings verdoem. Uitspraak in hierdie aansoek is op 12 Maart 1993 gegee, dit wil sê voordat die 1993 Grondwet op 27 April 1994 in werking getree het. Dit word aan die hand gedoen dat, in die lig van die hoofstukke oor fundamentele regte soos vervat in die grondwette, die beslissing ongrondwetlik is en nie in ander gevalle herhaal behoort te word nie. Die hof sal in die toekoms homoseksuele en lesbiese verhoudings in die ouer-kind verhouding moet akkommodeer, sou die beste belang van die betrokke kind dit vereis. Sien ook Costa 1994 De Rebus 914-918 en De Vos 1996 SAPR/PL 355-382 vir 'n bespreking van same-sex relations en die invloed daarvan op die ouer- 
kind verhouding. 
van ouerlike gesag in die ouer-kind verhouding nie, is nie debatteerbaar nie. ${ }^{16}$ Die belang van die kind word in die meeste gevalle nie in definisies voorop gestel nie, maar die ouerkind verhouding word in terme van gesag omskryf. Visser en Potgieter omskryf ouerlike gesag as die totaal van regte, verantwoordelikhede en verpligtinge wat die ouers uit hoofde van hul ouerskap het ten opsigte van hul minderjarige kinders, welke regte, verantwoordelikhede en verpligtinge in belang van die kinders uitgeoefen moet word. ${ }^{17}$ Ouerlike gesag kan op verskillende wyses tot stand kom. Beide ouers verkry dit in die geval van die binne-egtelike geboorte van hulle kind. Die moeder verkry alleen die gesag in die geval van die buite-egtelike geboorte van die kind. Die vader (saam met die moeder) verkry ouerlike gesag in die geval van die wettiging van ' $n$ buite-egtelike kind. Dieselfde geld in die geval van aanneming van 'n kind. ${ }^{19}$ 'n Wettige kind staan dus onder die gesag van albei haar ouers. Dit is egter nie te sê dat die reg die vader en die moeder op gelyke voet plaas in die besluitnemingsproses in die ouer-kind verhouding nie. ${ }^{20}$ 'n Buite-egtelike kind val onder die ouerlike gesag van haar moeder en die biologiese vader besit geen ouerlike gesag oor die kind nie.

Ouerlike gesag kom ter sprake ten aansien van die persoon van die kind (bewaring), die boedel van die kind, die regsoptredes van die kind, die benoeming van voogde vir die kind (voogdy) en die onderhoudsplig teenoor die kind. ${ }^{22}$ Bewaring van die kind beteken om haar daaglikse lewe te beheer, na haar opvoeding en opleiding om te sien,

16 Uiteenlopende standpunte bestaan ten aansien van die aard van ouerlike gesag. Sien Maré Gesinspolitiek 94-95 waar hierdie stelling gestaaf word.

17 Visser en Potgieter Familiereg 178. 18 Van der Vyver en Joubert Persone- en Familiereg 595, Barnard, Cronjé en Olivier Persone- en

Familiereg 281; Boberg Persons and the Family 315-316; Visser en Potgieter Familiereg 179 185.

19 Aanneming is ' $n$ formele proses waardeur ouerlike gesag oor die kind beëindig word en in ' $n$ ander persoon of persone gevestig word. Aanneming word uitvoerig gereël deur die Wet op Kindersorg 74 van 1983 soos gewysig in 1991 (Wysigingswet op Kindersorg 86 van 1991).

20 Calitz v Calitz 1939 AD 56. Sien ook McQuoid-Mason Street Law 37-38.

21 Hy kan wél by die hof aansoek doen om 'n bevel wat aan hom toegang tot die kind verleen. Sien verder Van Erk v Holmer 19922 SA 636 (W); B v S 19932 SA 211 (W); S v S 19932 SA 200 (W). Sien ook Govender 1997 Human Rights and Constitutional Law Journal of Southern Africa 28-29 vir 
'n bespreking vir die toekomstige posisie van die buite-egtelike vader in die ouer-kind verhouding. 22 Van der Vyver en Joubert Persone- en Familiereg 607; Visser en Potgieter Familiereg 185. 
te besluit met wie sy mag assosieer ${ }^{23}$ en na haar veiligheid om te sien. Regter King verduidelik die beheer en toesig element van ouerlike gesag in Kastan v Kastan soos volg:

\begin{abstract}
Custody of children involves day to day decisions and also decisions of longer and more permanent duration involving their education, training, religious upbringing, freedom of association and generally the determination of how best to ensure their good health, welfare and happiness.
\end{abstract}

Beheer oor die persoon van die kind is dié element van die ouer-kind verhouding wat daaglikse besluitneming vereis. ${ }^{25}$ Dit spreek vanself dat ouers beklee moet wees met ' $n$ kompetensie of vermoë om deel te neem aan die besluitnemingsproses waar verskillende aspekte van die kind se opvoeding binne die ouer-kind verhouding gereël word. Voor die inwerkingtreding van die 1993 Grondwet is hierdie kompetensie of vermoë getipeer as ouerlike gesag. Barnard, Cronjé en Olivier gaan verder en verklaar soos volg:

Ten einde die ouerlike gesag in hierdie opsig behoorlik te kan uitoefen, is dit noodsaaklik dat die ouers die kind moet kan dissiplineer en is die kind gehoorsaamheid aan die ouers verskuldig.

23 In $L v H 19922$ SA 594 (OK) moes regter Zietsman beslis of ' $n$ vader se ouerlike gesag oor sy ongetroude swanger 18-jarige dogter se inhoud van só 'n aard is dat die vader sy dogter en haar vriend met ' $n$ interdik kan laat verbied om mekaar te sien. Die rede vir die vader se besorgdheid aangaande die verhouding was die feit dat die 18-jarige se vriend (had) a tremendous influence over his daughter, whom he regarded as very immature for her age, and that her relationship with him was severely prejudicial to her future. Die hof het beslis dat die vader se ouerlike gesag wél van só ' $n$ aard is dat hy 'n interdik kan verkry om die verhouding tussen sy dogter en haar vriend stop te sit. Sien ook in dié verband Coetzee v Meintjies 19761 SA 257 (T); Meyer v Van Niekerk 19761 SA 252 (T); Gordon v Barnard 19771 SA 887 (K) en H v I 19853 SA 237 (K).

24 Kastan v Kastan 19853 SA 235 (K) 236E.

25 Ouers moet die kind van geskikte huisvesting voorsien asook van die nodige voedsel, kleding en geneeskundige hulp. Ouers moet dus aandag gee aan die ontwikkeling van die kind se liggaam, die vorming van die kind se karakter, die ontwikkeling van die kind se verstand en die godsdiensonderrig en kulturele vorming van die kind. Sien Maré Gesinspolitiek 98 waar die opvoedingsplig as een van die vernaamste verpligtinge van ouers in die ouer-kind verhouding uit gelig word. 
Twee verdere aspekte wat ' $n$ besluitnemingsproses binne die ouer-kind verhouding vereis is die onderhoudsplig tussen ouer en kind $^{27}$ en situasies waar die minderjarige kind by sekere regsgedinge betrek word en dan bygestaan word deur haar voog. ${ }^{28}$

Ouerlike gesag van enige betrokke ouer word beëindig deur die dood van die kind, die dood van die ouer, die meerderjarigheid van die kind, ${ }^{29}$ die regserkende huweliksluiting deur 'n minderjraige, die aanneming van die kind, die opheffing van ' $n$ aannemingsbevel en ' $n$ hofbevel.

\subsubsection{Judisiële inmenging met die ouer-kind verhouding}

Daar bestaan verskeie statutêre bepalings ingevolge waarvan die howe met die ouerlike gesag kan inmeng en dit selfs kan beëindig, bo en behalwe die feit dat die hof oor ' $n$ gemeenregtelike bevoegdheid as oppervoog beskik. ${ }^{31}$ Dit is duidelik dat daar nie wetgewing in die Suid-Afrikaanse reg bestaan wat uitdruklike bevoegdhede aan die howe verleen om oor die algemene besluitnemingsproses waar konflik binne die ouer-kind verhouding bestaan, te beslis nie. Die howe het slegs bevoegdhede om in te meng in die ouer-kind verhouding in die geval van die fisiese mishandeling of molestering van die kind, by egskeiding, ${ }^{33}$ en waar toestemming tot ' $n$ minderjarige

26 Barnard, Cronjé en Olivier Persone- en Familiereg 289.

27 Sien Spiro Parent and Child 385 waar hy die grondslag vir hierdie plig bespreek. Sien verder McQuoid-Mason Street Law 40 waar hy die tendens in die Suid-Afrikaanse reg verduidelik, naamlik dat die die reg ook 'n verpligting op kinders plaas om hulle ouers te onderhou. Hierdie tendens het sy ontstaan in die Romeins-Hollandse reg gehad.

28 Sien, in die algemeen Boberg Persons and the Family 469-515 aangaande die administrasie van die minderjarige kind se boedel. Hierdie twee aspekte van ouerlike gesag in die ouer-kind verhouding word normaalweg tuisgebring onder die term voogdy. Sien ook die Wet op Voogdy 192 van 1993.

29 Die privaatreg stel die algemene ouderdomsgrens van 21 jaar vas vir die verkryging van meerderjarigheid. Sien a 1 van die Wet op die Meerderjarigheidsouderdom 57 van 1972.

30 Barnard, Cronjé, Olivier Persone- en Familiereg 294; Van der Vyver en Joubert Persone- en Familiereg 626; Boberg Persons and Family 316-317; McQuoid-Mason Street Law 41-42; Visser en Potgieter Familiereg 190.

31 In Ex parte Kedar and Another 19931 SA 242 (W) 244E, dui regter Van Zyl aan dat dit gevestigde reg is dat die hooggeregshof die oppervoog van alle minderjariges is en dat die beste belang van die kind die primêre oorweging is wanneer die hof moet besluit om met die ouer-kind verhouding in te meng. Sien ook Visser en Potgieter Familiereg 193. Sien verder Maré Gesinspolitiek 103-109 vir 'n bespreking van die verskillende statutêre bepalings wat bevoegdhede aan die hof verleen om in te meng in die besluitnemingsproses in die ouer-kind verhouding. 
32 Wet op Kindersorg 74 van 1983 en die Wet op Voorkoming van Gesinsgeweld 133 van 1993. 33 Wet op Egskeiding 70 vn 1979 en die Wet op Huweliksaangeleenthede 37 van 1953. 
se huwelik verleen moet word. $^{34}$ Selfs die gesinsadvokaat word net by egskeidingsaangeleenthede as bemiddelaar gebruik. Sonnekus is van mening dat hierdie vermelde voorbeelde van gesanksioneerde inmenging met die ouerlike gesag bevestig dat die regte van die ouer nie inhoudsbevoegdhede van die een of ander subjektiewe reg van die ouer is nie, maar dat dit soos alle ander kompetensies deur die norme van die objektiewe reg bepaal en beperk word. ${ }^{36}$ Die regspleging in Suid-Afrika weerspieël egter nie sy teoretiese optimisme nie.

Gemeenregtelik het die hof as oppervoog die bevoegdheid om met die ouerlike gesag in die ouer-kind verhouding in te meng, slegs as hy van mening is dat sodanige stap in belang van die kind is en só 'n stap sal nie ligtelik gedoen word nie. Dit is eerder waar dat daar aan die kant van die howe terughoudenheid bestaan om ten aansien van die uitoefening van ouerlike gesag in te gryp en dat die kind gevolglik in sommige gevalle onvoldoende beskerming teen die misbruik daarvan geniet. In Calitz $v$ Calitz ${ }^{37}$ is beslis dat die hof net met die ouerlike gesag sal inmeng "on special grounds such as for example danger to the child's life, health or morals." In G v Superintendent, Groote Schuur Hospital, and Others ${ }^{38}$ het regter Seligson beslis dat die hof nie oor 'n diskresie beskik om kant te kies in die besluitnemingsproses in die ouer-kind verhouding nie en het hy eerder die saak op tegniese gronde beslis en nie op meriete nie. Die hof het beslis dat hy nie kan beveel dat 'n aborsie op minderjarige $N$ gedoen moet word (volgens $N$ se wens) of dat dit nié gedoen moet word nie (ooreenkomstig $N$ se moeder se wens). Die hof kan net beslis of die tegniese punte ten opsigte van die aansoek om 'n aborsie ingevolge die Wet op Vrugafdrywing en Sterilisasie ${ }^{39}$ nagekom is of nie. Hierdie beslissing weerspieël nie net 'n terughoudende gesindheid nie, maar eerder 'n onnodige terugdeinsing voor die

34 Huwelikswet 25 van 1961.

35 Wet op Bemiddeling in Sekere Egskeidingsaangeleenthede 24 van 1987.

36 Sonnekus 1992 THRHR 649-658. 
37 Calitz v Calitz 1939 A 56 63. Sien ook L v H 19922 SA 594 (OK).

38 G v Superintendent, Groote Schuur Hospital, and Others 19922 SA 594 (OK).

39 Wet op Vrugafdrywing en Sterilisasie 2 van 1975. 
regsbank se verantwoordelikheid.

In Coetzee $v$ Meintjies ${ }^{41}$ het regter Hiemstra beslis dat 'n vader as ouer en gesagdraer in die ouer-kind verhouding 'n persoonlikheidsbelang het, naamlik dat 'n kind gehoorsaamheid aan haar ouer verskuldig is. Minagting van die vader se ouerlike gesag deur sy kind of ' $n$ derde is 'n iniuria teenoor die vader, deurdat sy persoonlikheidsbelang geminag word. ${ }^{42}$ Dit is belangrik om te let op die redes wat die hof aanvoer vir die afwysing van die vader se aansoek om 'n interdik, naamlik dat die opvoedings- en versorgingsplig as elemente van die vader se ouerlike gesag verminder in verhouding tot die volwassenheid van die normale kind.

In $L v H^{43}$ het die hof eerstens beslis dat die vader nooit in die 18 jaar van sy dogter se lewe afstand gedoen het van sy ouerlike gesag nie en te alle tye volle beheer oor haar persoon gehad het en daarom kon die vader besluit met wie sy kan assosieer en met wie nie. Regter Zietsman beslis dat die hof nie op die feite voor hom kan waarneem dat die vader ooit onredelik was in die uitoefening van sy ouerlike gesag ten aansien van sy dogter nie. Laastens beslis die hof dat dit nie onredelik teenoor die ongebore baba is om die interdik toe te staan nie, aangesien dit nie seker is of die twee minderjarige partye wél met mekaar sal trou nie. Hierdie drie redes is volgens regter Zietsman genoegsaam om die vader se versoek om 'n interdik toe te staan. Wat die

40 Die Wet op Keuse oor die Beëindiging van Swangerskap 92 van 1996 erken in a 7(2) die swanger minderjarige se reg op keuse. Daar word in hierdie wetsontwerp voorsiening gemaak vir die keuse wat ' $n$ swanger minderjarige het, sou sy ' $n$ besluit neem om ' $n$ aborsie te ondergaan. Sy word geadviseer om met 'n dokter, of 'n vroedvrou, of 'n maatskaplike werker, of haar ouers, voog of vriende te konsulteer alvorens sy só 'n stap sal oorweeg. Haar weiering tot konsultasie kan egter nie haar reg op ' $n$ aborsie negatief beïnvloed nie. Dit word aan die hand gedoen dat die benadering wat die hof in G v Superintendent, Groote Schuur Hospital, and Others 19932 SA 255 (K) gevolg het, nie in die lig van die gees en strekking van die grondwette en die bestaan van hierdie wetsontwerp, in die toekoms deur ander howe nagevolg moet word nie.

41 Coetzee $v$ Meintjies 19761 SA 257 (T) 262C. In dié gewysde kom die eerste verwysings na die vraag of die vader in sodanige omstandighede wel suksesvol aansoek kan doen om ' $n$ interdik teen die onwelkome vryer, voor. Sonnekus 1992 THRHR 649650 verklaar tereg dat die afwesigheid van vroeëre gerapporteerde regspraak nie dien as gesag dat dié probleem nie voorheen bestaan het nie.

42 In Coetzee v Meintjies 1976 1 SA 257 (T) en Meyer v Van Niekerk 19761 SA 252 (T) het die hof beide daardie aansoeke in die lig van die omstandighede afgewys. Regter Steyn het eers in Gordon $v$ Barnard 19771 SA 887 (K) 'n interdik aan die vader van 'n 18-jarige dogter teen die onwelkome besoeke van ' $n$ 29-jarige man toegestaan. Die vader in $H$ v I 19853 SA 237 (K) was ook suksesvol 
met sy aansoek om 'n interdik teen die man van 23 wat verantwoordelik was vir die swangerskap van sy 17 -jarige dogter.

43 L v H 19922 SA 594 (E). Sien vn 23 hierbo vir die uiteensetting van die feite van die saak. 
hof egter uit die oog verloor het, was dat hy in dié omstandighede as die oppervoog van die 18-jarige en 'n ongeborene moes optree. Dit blyk duidelik dat die hof nie die beste belang van die 18-jarige in aanmerking geneem het in die afweeg van belange tussen die vader se persoonlikheidsbelang en die dogter se reg op keuse nie. Die hof was tevrede met die vader se subjektiewe verklaring dat die dogter nie volwasse is nie en het die reg van keuse waaroor die 18-jarige beskik, ontken. Die hof het eerder kennis geneem van die ongebore baba se beste belang as dié van haar moeder. Dit is duidelik dat die bona fides van die vader swaarder geweeg het as die beste belang van die 18-jarige meisie.

\subsection{Gewoonteregtelike gesinstrukture}

'n Multikulturele gemeenskap is een van Suid-Afrika se uitstaande kenmerke. Dit is dus noodsaaklik om ook aandag te skenk aan die ouer-kind verhouding en ouerlike gesag ingevolge die gewoontereg, aangesien die gemeenskap in die "nuwe" Suid-Afrika sowel uit Westerse kerngesinstrukture as uit ('n meerderheid) gewoonteregtelike gesinne bestaan.

Kimathi stel dit duidelik dat die huwelik en die gesin die twee basiese elemente van alle Afrikakultuur en -tradisie vorm. ${ }^{45}$ Sy beklemtoon die feit dat die huwelik en gesinstruktuur deur gemeenskaps- of samelewingsveranderinge beïnvloed word. Op sy beurt identifiseer Olmesdahl die vernaamste faktore wat die gewoonteregtelike gesin se aard en omvang beïnvloed, naamlik verstedeliking, die behuisingskrisis en verpligte migrasie. ${ }^{46}$ Burman verklaar dat gewoontereg in die praktyk gedurigdeur verander (veroorsaak deur groot sosiale veranderinge) en nie in wese dit is wat in die

44 Hierdie kritiek word gelewer in die lig van die gees en strekking van die fundamentele regte hoofstukke in die grondwette. Voorts het die hof ook nie die maatstaf soos neergelê in Coetzee $v$ Meintjies 19761 SA 257 (T), naamlik dat ouerlike gesag afneem met die vordering van die minderjarige se volwassenheidspeil, in ag geneem nie. Dit word aan die hand gedoen dat regter Zietsman se uitspraak nie in die toekomstige beoordeling van die vader se ouerlike gesag ten aansien van sy adolessente dogter sal staan of nagevolg moet word nie.

45 Kimathi Marriage and Family 1994 12. Sien ook Nhlapo 1991 AJ 135-146. 46 Olmesdahl Family Life 1987 93-106. Nhlapo Future of Family Law 10, 12-13, identifiseer die volgende faktore wat ' $\mathrm{n}$ invloed gehad het op die gewoonteregtelike ouer-kind verhouding: 
teorie as gewoontereg voorgehou word nie. ${ }^{47}$ Daar moet ook in gedagte gehou word dat kulturele patrone en tradisie in die gewoontereg beïnvloed word deur en verskil as gevolg van etniese diversiteit. Ten aansien van die swart bevolkingsgroepe in Suid-Afrika het apartheidswetgewing aan die een kant en gewoonteregtelike bepalings aan die ander kant gegeld. Die Suid-Afrikaanse reg het, weens die poligamiese aard van gewoonteregtelike huwelike volhard in die ontkenning daarvan. Hierdie sosiale realiteit is ontken en die moderne gewoonteregtelike enkelvoudige gesin het ontwikkel sonder dat die SuidAfrikaanse reg regstegnies daarvan kennis geneem het. In hierdie verband gaan as voorbeeld net aandag gegee word aan die Zoeloe (amaZulu) gesinstrukture in die KwaZulu-Natal konteks.

Dit blyk duidelik dat die tradisionele gewoonteregtelike familie vir stabiliteit verantwoordelik was binne amaZulu-stamverband en die lede moes kollektief 'n emosionele, ekonomiese en politieke ondersteuningstelsel vir die stam gevorm het. Omdat daar nie op individualisme gefokus is nie, het die ouer-kind verhouding en ouerlike gesag nie duidelik en eksplisiet gefigureer nie. ${ }^{48}$ Daar bestaan ' $n$ aantal faktore wat aanleiding gegee het tot die modernisering van die gewoonteregtelike gesin, naamlik die kodifikasie van gewoontereg in Natal vanaf $1880{ }^{49}$ kolonisasie, verstedeliking en migrasie, toenemende erkenning van Westerse individualisme en die invloed van Christelike sendingstasies op die plattelend. $^{50}$

Die belangrikste verandering in die sosiale struktuur van die tradisionele familie is die verswakking van die omvangryke bloedverwantskap wat binne 'n isishlobo gegeld het. Wanneer die moderne gewoonteregtelike gesin bestudeer word, moet daar onderskeid getref word tussen die verstedelikte en plattelandse gewoontregtelike

Between them, Christianity, labour migration, influx control and wage earning eroded the stereotype of the extended family ... Add to that unemployment, poverty, urban overcrowding and the erosion of the material underpinnings of the kinship ethic and the picture is bleak indeed.

47 Burman 1991 AJ 36-51. Dit volg dus dat die gewoontereg wat deur die howe geïnterpreteer en toegepas word nie noodwendig die gewoontereg van die praktyk verteenwoordig nie. 
48 Sien Maré Gesinspolitiek 116-120 vir 'n kort oorsig oor tradisionele Zoeloe isihlobo (familie) wat serk gefundeer was op 'n patriargale gesagshiërargie.

49 Tans is die gewoontereg in KwaZulu-Natal gekodifiseer in die KwaZulu-Natal Wetboek 16 van 1985 en Prok R151 van 1987. Die twee wetboeke se bepalings kom ooreen en vir doelmatigheidsredes word daarna verwys as die KwaZulu-Natal Wetboeke.

50 Olmesdahl Family Life 9396. 
gesin. Die ekonomiese oorlewing van baie gesinne op die platteland steun op die afwesigheid van die vader. As broodwinner bevind hy homself in die stad, terwyl sy gesin op die platteland agtergelaat word. Die tendens hier is dat gesinne aangetref word sonder ' $n$ vader se aanwesigheid in die ouer-kind verhouding. Hier is dus nie sprake van ' $n$ kerngesin nie. ${ }^{51}$ Die moeder is dus die gesagdraende party in die ouerkind verhouding. In plaas van om met enkelouerskap opgesaal te word, verkies moeders in hierdie situasie om eerder te steun op die tradisionele isihlobo. Hier is sprake van kinders se respek vir en gehoorsaamheid aan die ouer familielede. Die ouer-kind verhouding in verstedelikte gewoonteregtelike gesinne (umndeni (kerngesin)) word gekenmerk deur konflik, aangesien die minderjarige kind nie meer respek en gehoorsaamheid toon aan die ouer familielede nie. Zoeloemans is daartoe genieg om aan die tradisionele elemente van die familieeenheid vas te hou en is verder nie bereid om hul rol as mede-opvoeders in die ouer-kind verhouding te aanvaar nie. ${ }^{52}$ Verder gee wydverspreide armoede ook aanleiding tot die verswakte ouerlike gesag in die ouer-kind verhouding, want daar kan nie na behore voorsien word in die materiële en emosionele behoeftes van die kinders nie. Waar ouderdom tradisioneel nie 'n faktor was wat meerderjarigheid bepaal het nie, maar eerder die aanbreek van puberteit, het dié tendens verander as gevolg van die verwesteringsproses van die gewoonteregtelike umndeni.

Olmesdahl dui tereg daarop dat daar nie in die Suid-Afrikaanse reg 'n instrument bestaan waarmee judisieel ingemeng kan word in die gewoonteregtelike ouer-kind verhouding nie. Sou die bestaande wetgewing daarvoor gebruik word, kan dit ernstige gevolge hê:

If the magistrate decided that a child is in need of care, he will be faced with a child belonging to a different race group with different cultural and child-rearing practices.

51 Daar word eerder na só 'n gesinstipe verwys as 'n enkelouer-gesin. Sien Omesdahl "Family Life" 93-99.

52 Omesdahl "Family Life" 93 98. Die Zoeloevrou het ook addisionele Westerse rolle in die verstedelikte gewoonteregtelike gesin aangeneem. 
53 Olmesdahl Family Life 9399. 
Tog moet daar gelet word op 'n aantal bepalings in die KwaZulu-Natal Wetboeke, aangesien dit die regsposisie van die amaZulu reël, ongeag of hulle deel is van ' $n$ verstedelikte of plattelandse gewoonteregtelike gesin. Artikel 14 van die KwaZulu-Natal Wetboeke bepaal dat 'n Swart persoon 'n wettige meerderjarige word wanneer hy trou of die ouderdom van een-en-twintig jaar bereik. ${ }^{54}$ Artikel 19 van die KwaZulu-Natal Wetboeke reël die huidige posisie van die familiehoof se aanspraak en beheer oor die gesin se eiendom. Hy het 'n aanspraak op 'n "redelike aandeel van die verdienste van die minderjarige lede van die familie ...." In die tradisionele gewoontereg het die familiehoof beheer en toesig oor sy minderjarige kinders gehad. Artikels 27-35 van die KwaZulu-Natal Wetboeke bepaal dat wanneer ' $n$ hof 'n bevel ten aansien van die toesig en beheer oor die kind moet maak, die beste belang van die kind in ag geneem moet word. In Msweli $v$ Msweli ${ }^{56}$ het die hof die volgende beslis:

In original customary law the father indeed, had absolute rights to the custody of his children, but these rights with the passage of time, the advancement of the Black peoples, the effect of legislation governing children have completely negated any such right, more especially as the court, being the upper guardian of all Black children, has, in the ordinary course, looked to the interest of the children themselves.

\subsection{Gevolgtrekking}

54 Volgens die Wet op Meerderjarigheidsouderdom 57 van 1972 word alle persone geag meerderjarig te wees by bereiking van die ouderdom van 21 jaar. Indien die bepalings van hierdie wet en a 14 hierbo genoem saamgelees word, word dit duidelik dat meerderjarige swart vroue nie langer onder die gesag van die familiehoof staan nie, maar vrylik roerende en onroerende eiendom kan verkry, en ten volle handelingsbevoeg en verskyningsbevoeg is.

55 Sien a 19 van die KwaZulu-Natal Wetboeke. Kragtens die huidige voorskrifte is die familiehoof nie geregtig op die verdienste van meerderjarige kinders of ander lede van sy familie of ander inwoners van die kraal nie. Voorts bepaal aa 20 en 21 van die KwaZulu-Natal Wetboeke dat die familiehoof die gesamentlike huiseiendom primêr moet aanwend in belang van en tot voordeel van die besondere huis en hy mag nie een huis verryk ten koste van 'n ander of ten aansien van iemand anders nie. Sien ook Olivier Indigenous Law 41-47 vir 'n bespreking van 
die regsvoorskrifte daargestel deur die KwaZulu-Natal Wetboeke ten aansien van die bestuur van die verskillende huishoudings wat onder die beheer van die familiehoof val.

56 Msweli v Msweli 1985-6 AC (N-E) ongerapporteerd, soos gevind in Olivier ea Indigenous Law 83-84. 
In Suid-Afrika behels ouerlike gesag in die ouer-kind verhouding die gesag van die ouers oor die kind uit hoofde waarvan die ouer bevoeg is om sekere besluite ten aansien van die kind te neem en in die uitvoering daarvan gehoorsaamheid van die kind te eis. In die SuidAfrikaanse positiewe reg gaan ouerlike gesag ook gepaard met verpligtinge om huisvesting, voedsel, kleding, geneeskundige hulp asook 'n gepaste opvoeding aan die kind te verskaf. ' $n$ Ouer het onteenseglik as deel van sy/haar ouerlike gesagsbevoegdhede die reg om onder andere te bepaal met wie sy/haar kind in laasgenoemde se belang sal assosieer, net soos die ouer die opvoedingsverantwoordelikheid het om die kind ten beste vir die volwasse lewe voor te brei en dienooreenkomstig kan besluit om byvoorbeeld toestemming tot huweliksluiting of kontraksluiting vir sy/haar kind te gee of te weerhou. Alhoewel die meerderjarigheidsouderdom in die Suid-Afrikaanse reg 21 jaar is vir beide geslagte, kan ouers self in die gesinstruktuur besluit wanneer hulle betrokke kinders volwasse is. Soms geld ouerlike gesag in die ouer-kind verhouding tot na die bereiking van dié meerderjarigheidsouderdom.

Voorts is dit ook duidelik dat die veranderde sosio-ekonomiese en politieke elemente in die Suid-Afrikaanse gemeenskap ook 'n invloed gehad het op die tradisionele gewoonteregtelike familie-eenheid. Duidelik waarneembaar is die verskille in die ouer-kind verhouding tussen verstedelikte en plattelandse gesinne. By eersgenoemde is ' $n$ verswakte ouerlike gesag teenwoordig en by laasgenoemde is slegs die moeder beklee met ouerlike gesag, wat tog sterker figureer as by die ouer-kind verhouding in verstedelikte gebiede. In die verstedelikte gewoonteregtelike gesin is daar sprake van 'n kerngesin. Dit is egter nie die geval by die plattelandse gewoonteregtelike gesin nie.

Daar is ' $n$ dringende behoefte aan 'n instrument waarmee die emosioneel en fisiessorgbehoewende kind in die gewoonteregtelike gesin te hulp gesnel kan word. Wat ook duidelik blyk is dat die Suid-Afrikaanse familiereg teen die einde van 1993 oor 'n dualistiese karakter beskik. Hierdie familieregdualisme word aangespreek deur die bepalings van die Grondwette en hou noodwendige en noodsaaklike regsveranderinge 
57 A 27(5) van die KwaZulu-Natal Wetboeke bepaal spesifiek dat voogdyskap ten aansien van minderjariges ook in die moeder van sodanige kinders setel. 
vir die ouer-kind verhouding in die multikulturele gemeenskap in.

\section{Posisie na die 1993 Grondwet en die 1996 Grondwet}

\subsection{Inleiding}

$\mathrm{Na}$ die inwerkingtreding van die grondwette ontstaan die vraag hoe die bepalings ten aansien van fundamentele regte die ouer-kind verhouding in die multikulturele SuidAfrikaanse gemeenskap kan beïnvloed. ${ }^{59}$ Daar word gepoog om die verskeidenheid van belange in die Suid-Afrikaanse gemeenskap te akkommodeer en regverdigheid teenoor almal te verseker. ${ }^{60}$ Twee van die vernaamste kenmerke van die grondwette is hulle oppergesag $^{61}$ en die toetsingskompetensie van die konstitusionele hof ${ }^{62}$ ten aansien van grondwetlike aangeleenthede.

Hoofstuk 3 van die 1993 Grondwet en hoofstuk 2 van die 1996 Grondwet handel oor fundamentele regte. Hierdie hoofstukke bind alle regeringsinstellings wat wette maak en regsreëls uitvoer ${ }^{63}$ en dit bind ook die howe. ${ }^{64}$ Verhoudings tussen private inidvidue en instanies kan ook deur die bepalings van die Handves van Regte geraak word. ${ }^{65}$ Wanneer 'n hof enige regsreël uitlê en toepas, moet die hof die gees, strekking en oogmerke van die Handves behoorlik in ag neem.

58 Sien Nhlapo Future of Family Law 1015 vir 'n bevestiging van die feit dat die ouer-kind verhouding nie onsensitief staan teenoor die multikulturele gemeenskap waarin dié verhouding aanwesig is nie.

59 Nhlapo Future of Family Law 1012 stel dit duidelik dat die ouer-kind verhouding in die nuwe Suid-Afrikaanse gemeenskap soos volg saamgestel kan word, naamlik ... single-parent families, reconstituted families (with or without children), separated spouses and cohabiting couples (heterosexual or homosexual).

60 Dié doelwit word uitdruklik genoem in die 1993 Grondwet se Aanhef: Nademaal daar 'n behoefte bestaan om 'n nuwe bestel waarin alle Suid-Afrikaners geregtig sal wees op 'n gemeenskaplike Suid-Afrikaanse burgerskap in 'n soewereine en demokratiese regstaat waarin daar gelykheid tussen mans en vroue en mense van alle rasse is sodat alle burgers in staat is om hulle fundamentele regte en vryhede te geniet en uit te oefen; ... .

61 A4(1) van die 1993 Grondwet en a 2 van die 1996 Grondwet.

62 A 98(1) van die 1993 Grondwet en a 167(3)(a) van die 1996 Grondwet.

63 A 7(1) van die 1993 Grondwet en a 8(1) van die 1996 Grondwet. 
64 A 4(2), 98(4), bylae 3 en a 104(4) van die 1993 Grondwet. A 8(1) van die 1996 Grondwet is die ekwivalent van a 4(2), 98(4), bylae 3 en a 104(4) van die 1993 Grondwet.

65 Sien, die algemeen, Wolhuter 1996 SAPR/PL 512-527 vir 'n bespreking van die horisontale en vertikale werking van die Grondwette.

66 A 35(3) van die 1993 Grondwet en a 39(2) van die 1996 Grondwet. 


\subsection{Gewoontereg en die Grondwette}

Die grondwette verleen op verskillende maniere erkenning aan die gewoontereg of inheemse reg. ${ }^{67}$ Hierdie erkenning is deurgans onderworpe aan die bepalings ten aansien van fundamentele regte in beide grondwette. Dit beteken dat reëls van die gewoontereg getoets sal kan word aan fundamentele regte soos vervat in die toepaslike hoofstukke. Menige skrywers is egter van mening dat vanweë die aard van die gewoontereg dit nie só 'n toets sal kan deurstaan nie. ${ }^{68}$ Die aard van gewoontereg en die aard van die grondwette is nie versoenbaar nie. Die grondslag van fundamentele regte is geleë in die erkenning van die individu se regte. Daarteenoor is die grondslag van die gewoontereg kommunalisme. Dlamini verklaar egter dat "... customary law is in itself not in conflict with the idea of human rights." ${ }^{70}$

Artikel 229 van die 1993 Grondwet bepaal dat alle bestaande wette bly voortbestaan totdat dit vervang word deur 'n bevoegde gesag. Sodanige wette sluit artikel 1 van die $W_{\text {ysigingswet op Bewysreg }}{ }^{71}$ in. Hierdie artikel bepaal dat Suid-Afrikaanse howe geregtelik kan kennis neem van die gewoontereg sover dit nie indruis teen die openbare belang of natuurlike geregtigheid nie. Artikel 15(3)(a) van die 1996 Grondwet bepaal dat geen bepaling in hoofstuk 2 wetgewing belet wat 'n stelsel van persone-en familiereg, nagevolg deur persone wat 'n bepaalde tradisie en/of godsdiens aanhang, daarstel nie. ${ }^{72}$ Artikel 15(3)(b) van die 1996 Grondwet bepaal

67 Kerr AJ "Customary Law, Fundamental Rights, and the Constitution" 1994 SALJ 720-735 722 is van mening dat waar die 1993 Grondwet in hoofstuk 3 melding maak van gewoontereg en in hoofstuk 11 en beginsel 13 in bylae 4 melding maak van inheemse reg, dit as sinonieme bedoel word.

68 Bekker JC "How Compatible is African Customary Law with Human Rights? Some Preliminary Observations" 1994 THRHR 440-447 441; Dlamini CRM "The Role of Customary Law in Meeting Social Needs" 1991 AJ 71-85 71; De Koker JY "Die Status van die Inheemse reg in die Suid-Afrikaanse regsisteem na 27 April 1994" 1996 TRW 112-122 114-115; Kerr 1994 SALJ 720 724-729.

69 Dlamini 1991 AJ 7173 gee 'n verduideliking van kommunalisme: The context of family, clan, and ethnic solidarity or the kinship network, provided the framework within which individuals exercised their economic, political and social liberties and abilities, and provided restraints upon arbitrary official action that might otherwise have prevailed.

70 Dlamini 1991 AJ 71 73. 71 Wysigingswet op Bewysreg 45 van 1988. 72 A 15(3)(a) en (b) van die 1996 Grondwet is die ekwivalent van a 14(3)(a) van die 1993 
Grondwet. Waar a 14 (1993) erkenning verleen aan wetgewing wat 'n stelsel van persone- en familiereg daarstel, gebaseer op 'n bepaalde godsdiens, erken a 15 (1996) wetgewing wat 'n stelsel van persone- en familerg gebaseer op tradisie en/of godsdiens daarstel. 
egter:

Erkenning ingevolge paragraaf (a) moet met hierdie artikel en die ander bepalings van die Grondwet bestaanbaar wees.

Op sy beurt bepaal artikel 33(2) van die 1993 Grondwet dat geen regsreëls, hetsy 'n reël van die gemenereg, gewoontereg of wetgewing, enige reg verskans in hoofstuk 3 , kan beperk nie. ${ }^{73}$ Artikel 33(3) van die 1993 Grondwet bepaal dat verskanste regte in hoofstuk 3 nie só uitgelê moet word dat dit die bestaan van enige ander regte of vryhede in die gemenereg, gewoontereg of wetgewing, ontken nie. Artikel 36(2) van die 1996 Grondwet bepaal slegs die volgende:

Behalwe soos in subartikel (1) of in enige ander bepaling van die Grondwet bepaal, mag geen regsvoorskrif enige reg wat in die Handves van Regte verskans is, beperk nie.

Voorts bepaal artikel 35(3) van die 1993 Grondwet dat by die uitleg van enige wet en die toepassing en ontwikkeling van die gemenereg en gewoontereg, die hof die gees, strekking en oogmerk van hoofstuk 3 behoorlik in ag moet neem. Dié artikel kan gebruik word om ' $n$ balans te vind tussen artikel 14 en 33 van die 1993 Grondwet. Artikel 39(2) en (3) van die 1996 Grondwet kan nie op dieselfde wyse gebruik word om 'n balans te vind tussen die Handves van Regte en die gewoontereg nie. Die rede daarvoor is dat artikels 15 en 36 van die 1996 Grondwet nie 'n inherente konflik tussen die gewoontereg en fundamentele regte beliggaam nie. Sodanige konflik word eerder deur die verskillende bepalings van artikel 39 beliggaam. Hierdie artikel bepaal dat wanneer 'n hof wetgewing interpreteer of die gemenereg en/of die gewoontereg bevorder, die hof die gees, strekking en oogmerke van die Handves in gedagte moet hou. Voorts ontken die Handves nie die bestaan van enige regte en vryhede soos aanwesig in die gewoontereg, gemenreg of wetgewing nie, solank dit net nie met die bepalings van hoofstuk 2 bots nie. Daar kan aangevoer word dat die bepalings in artikel 211(3) van die 1996 Grondwet gebruik kan word om hierdie 
73 A 36 van die 1996 Grondwet is die ekwivalent van a 33 van die 1993 Grondwet en dien as die beperkingsklousule van die Handves van Regte. 
potensiële konfliksituasie op te los. ${ }^{74}$ Artikel 211(3) bepaal dat:

Die howe moet die gewoontereg toepas wanneer dié reg toepasbaar is, behoudens die Grondwet en enige wetgewing wat spesifiek oor gewoontereg handel.

Wat baie duidelik blyk is dat die gewoontereg as sulks deur die grondwette erken word as 'n regstelsel wat gelyke erkenning en aanwending vind in die bestaande positiewe reg. Wat egter ook waar is, is dat die fundamentele regte verskans in die grondwette van toepassing is op die gewoontereg. Al die implikasies wat die toepassing van fundamentele regte op die gewoontereg inhou, is nie duidelik nie. Dit is egter duidelik dat die twee elemente in die Suid-Afrikaanse reg in konflik met mekaar staan. 'n Moontlike oplossing wat deur skrywers aangevoer word, is dat dit nie die bedoeling van die grondwetskrywers kon gewees het om die gewoontereg aan die een kant te erken, maar dit dan deur toetsing in die howe ongedaan te maak nie. Dit moet volgens hulle moontlik wees om 'n middeweg te vind en dit is juis daar waar die uitdaging vir die regshervormers lê, naamlik om 'n versoening te bewerkstellig eerder as om gewoontereg eenvoudig ongeldig te verklaar. ${ }^{75}$

\subsection{Grondwetlike beskerming verleen aan kinders ${ }^{76}$}

There are no universally recognised criteria for determining

74 A 181(2) van die 1993 Grondwet bepaal dat die inheemse reg onderworpe is aan regulering deur die reg. Dié reg sluit bepalings van die 1993 Grondwet in, aangesien a 4 van hierdie Grondwet dié reg as die hoogste gesag in die Republiek daarstel. Voorts bepaal beginsel 13 in Bylae 4 van die 1993 Grondwet dat die inheemse reg, soos die gemenereg, deur die howe erken en toegepas moet word, onderworpe aan die fundamentele regte in die 1993 Grondwet en aan wetgewing wat spesifiek daaroor handel.

75 Sien Maré Gesinspolitiek 184-191 vir die bespreking van 'n moontlike instrument waarvolgens die gewoonteregtelike familie suksesvol in die positiewe reg geïnkorporeer kan word. Sien ook Nhlapo Future of Family Law 10 17-20 vir 'n moontlike Suid-Afrikaanse oplossing. De Koker 1996 TRW 112 120 verklaar dat daar belangrike praktiese stappe geneem sal moet word ten einde die Grondwetlike erkenning van die inheemse reg as volwaardige regstelsel binne die Suid-Afrikaanse regsisteem te aktualiseer. 
76 Kinders onder die ouderdom van 18 jaar word, in terme van a 30(3) van die 1993 Grondwet en a 28(3) van die 1996 Grondwet, geag persone beklee met fundamentele regte te wees, ongeag ras of geslag. Hierdie grondwetlike ouderdomsgrens verskil van die privaatreg se bepaling van 21 jaar. 
the status of childhood. Child and adult are flexible social categories, which are defined according to cultural stereotypes of ageing and the constraints of social and economic circumstances.

Artikel 8 van die 1993 Grondwet bevat die "gelykheidsklousule" en artikel 30 van dieselfde Grondwet reël uitdruklik die posisie van die kind in die Suid-Afrikaanse gemeenskap. ${ }^{78}$ Die saamlees van artikels 8 en 30 dui daarop dat 'n kind onder die ouderdom van 18 jaar ook as 'n persoon beklee met fundamentele regte geag word en dit hou in dat die gelykheidsklousule ook geld ten aansien van elke kind in die Suid-Afrikaanse gemeenskap. ${ }^{79}$ Artikel 30 van die 1993 Grondwet raak ouerlike gesag soos deur die meeste Suid-Afrikaanse familieregskrywers gedefinieer. Hierdie artikel omlyn die regte en verpligtinge van die ouers uit hoofde van hul ouerskap teenoor hulle kinders. Die verwysing na ouerlike sorg kan daarvan aanduidend wees dat die reg van ouers om vir hulle kinders te sorg en hulle op te voed deur die welsyn van die kind bestem moet word en dat juis die welsyn van die kind die ouerlike verpligtinge jeens haar begrond. ${ }^{80}$ Verder verskans artikel 30(3) die gemeenregtelike reël met betrekking tot enige kind (ongeag haar sorgbehoewende aard) naamlik die beste belang van die $k i n .^{81}$ Hierdie subartikel geld as kwalifikasie vir die res van die

77 Bennet Human Rights. Sien ook Maré Gesinspolitiek 79-80 vir 'n aanduiding hoe die gemeenskap definitiewe lyne getrek het tussen kinders en volwassenes en hoe hierdie onderskeid die ouer-kind verhouding beïnvloed.

78 A 9 van die 1996 Grondwet bevat die gelykheidsklousule en a 28 van die 1996 Grondwet omskryf die fundamentele regte van die kind. In die 1996 Grondwet dui die saamlees van a 9 en 28 daarop dat ' $n$ kind onder die ouderdom van 18 jaar as ' $n$ persoon geag word in die 1996 Grondwet. Dit beteken dat a 9 ten aansien van elke kind in die Suid-Afrikaanse gemeenskap geld.

79 Sien Bennett Human Rights 99-101 vir 'n volledige bespreking van die implikasies van a 30 van die 1993 Grondwet vir die kind in die multikulturele ouer-kind verhouding. Visser en Potgieter Family Law 387 verduidelik die invloed van dié fundamentele regte soos volg: All legal principles relating to the position of children are subject to these fundamental rights of children. It is, however, as yet uncertain how these rights will influence the application and development of the law.

80 Daar moet egter nie hieronder verstaan word dat die begrip ouerlike sorg die moderne regstegniese begrip vir ouerlike gesag is nie, want eersgenoemde omvat net ' $n$ enkele aspek van ouerlike gesag.

81 Die begrip die beste belang van die kind asook die inhoud van dié begrip is moeilik definieerbaar. In Deijl v Deijl 19664 SA 260 (R) $261 \mathrm{H}$ word die beste belang van die kind soos volg gedefinieer: 
artikel deurdat al die regte waarop die kind geregtig is, uitgeoefen moet word tot voordeel en in die beste belang van die aanspraakmakende kind.

Die Wet op Bemiddeling in Sekere Egskeidingsaangeleenthede ${ }^{83}$ maak voorsiening vir die amp van gesinsadvokaat wat aan die hof sekere inligting kan en moet voorsien sodat die hof ' $n$ beslissing in die beste belang van die kind kan maak. Tog kan dit nie in enige situasie geskied nie, maar slegs by egskeidings, wysigings van bestaande egskeidingsbevele waar kinders betrokke is en waar die hof as oppervoog optree. Die gesinsadvokaat neem die gees en strekking van hoofstukke 3 en 2 van die Grondwette in ag by ondersoeke na die beste belang van die kind. Die regsontwikkeling na 27 April 1994 is dus dat die gesinsadvokaat nou ook erken dat die kind geregtig is om deel te neem aan die besluitneming oor haar toekoms. Haar wense en voorkeure word in ag geneem en word dan aan die hof voorgehou as die behoeftes van die kind.

McCall v McCall ${ }^{85}$ het onder andere gehandel oor die gewig wat aan 'n kind se voorkeure geheg moet word in 'n toesig- en beheerbevel. Regter King beslis dat hier met twee bevoegde ouers gehandel word en dat besondere waarde geheg moet word aan R ('n 12jarige seun) se voorkeur en behoeftes. Regter King stel dit duidelik dat sodanige voorkeur in ag geneem sal word waar die kind oor die nodige oordeelsvermoë beskik en 'n gepaste intellektuele oordeel kan vorm (ongeag die kind se ouderdom). Of die kind oor die vermoë beskik, moet wetenskaplik geëvalueer word en daar moet vasgestel word waarom die kind sodanige voorkeur het. Om verder vas te stel wat in die beste belang van die kind is, lys regter King 'n aantal faktore wat verder deur die hof oorweeg kan word. ${ }^{86}$ Dit is onder andere die liefde, waardering en ander emosionele bande wat 'n ouer met ' $n$ kind het, die karakter en

The interests of the minor mean the welfare of the minor and the term welfare must be taken in its widest sense to include economic, social, moral and religious considerations. Emotional needs and the ties of affection must also be regarded and in the case of older children their wishes in the matter cannot be ignored. Sien ook Heaton 1990 THRHR 95-99 vir 'n bespreking van die vae inhoud van hierdie begrip.

82 Sien Maré Gesinspolitiek 138-140 vir 'n bespreking aangaande die inhoud en betekenis van die begrip beste belang van die kind. 
83 Wet op Bemiddeling in Sekere Egskeidingsaangeleenthede 24 van 1987.

84 Die gesinsadvokaat maak gebruik van 'n deskundige om die wense en voorkeure van die kind te bepaal. Dit word wetenskaplik geëvalueer.

85 McCall v McCall 19943 SA 201 (K).

86 McCall v McCall 19943 SA 201 (K) 205B-F. 
temperament van die ouer en die impak daarvan op die kind, die kommunikasievermoë van die ouer met die kind en die ouer se vermoë om in die kind se emosionele en fisiese behoeftes te voorsien. Regter King beslis na die oorweging van die kind se voorkeur, die gesinsadvokaat se aanbeveling en die gelysde faktore dat $\mathrm{R}$ se vader toesig en beheer moet verkry.

Artikel 28 van die 1996 Grondwet gaan verder as artikel 30 en bied 'n omskrywing vir die begrip ouerlike sorg. Die verwysing na gesinsorg, ouerlike sorg en gepaste alternatiewe sorg kan daarvan aanduidend wees dat die veranderde verhoudings waarin 'n kind haarself in die gemeenskap kan bevind (anders as die tradisionele kerngesin) deur die 1996 Grondwet erken word. Dit moet steeds beklemtoon word dat dié begrippe nie as die moderne regstegniese sinoniem van ouerlike gesag beskou kan word nie.

Artikels 30 (1993) en 28 (1996) vind net aanwending ten aansien van kinders onder die ouderdom van 18-jaar, wat inhou dat die kind se ouers namens haar die regte gelys in die onderskeie subartikels teen die staat kan afdwing. Maar daar is ook 'n teenpool in hierdie artikels, naamlik dat die staat beveel word om sorg te dra dat die regte genoem aan die kind verleen en verskaf word. Dit wil dus voorkom of die staat die ouerlike gesag in die ouer-kind verhouding oorneem. Hier is dus sprake van 'n klemverskuiwing. Die klem verskuif vanaf die ouers se regte en verpligtinge asook die staat se regte en verpligtinge na die aanspraakregte van die kind teenoor haar ouers en die staat.

Die hooggeregshof as gemeenregtelike oppervoog van kinders is beklee met vertikale gesag ten aansien van die ouer-kind verhouding. Daarom is artikels 30 (1993) en 28 (1996) van toepassing op die ouer-kind verhouding, ongeag die behoefte of gebrek

87 McCall v McCall 19943 SA 201 (K) 209F-G.

88 Dit is moontlik om dié klemverskuiwing te interpreter asof dit aan die kind 'n aanspraaksreg 
verleen teenoor haar ouers en/of die staat. Byvoorbeeld die kind se reg dat haar ouers of die staat ' $n$ besluit neem rakende die voorsiening van haar regte wat in haar beste belang en tot haar voordeel is. 
aan ouerlike sorg. ${ }^{89}$ Artikels 30(3) van die 1993 Grondwet en 28(2) van die 1996 Grondwet maak dus die deur oop vir 'n kind wat konflik ervaar in die besluitnemingsproses in die gesin om die hof as oppervoog te nader, te versoek dat haar beste belang vasgestel moet word en dat 'n bevel dienooreenkomstig gegee moet word. Tog is dit tans nog vir ' $n$ minderjarige moeilik om locus standi te verkry in 'n hofgeding wat voortspruit uit konflik in die ouer-kind verhouding en wat oor haar welsyn handel. Artikel 22 van die 1993 Grondwet verleen aan elke persoon die reg om beregbare geskille deur 'n geregshof of 'n ander onafhanklike en onpartydige forum te laat besleg. Artikel 34 van die 1996 Grondwet handel met die locus standi vraagstuk en moet saamgelees word met artikel 28(1)(h) van dieselfde Grondwet. Dit is duidelik dat die kind die hof ingevolge die 1996 Grondwet kan nader vir 'n beslissing wat ' $n$ balans daar kan stel in die besluitnemingsproses in die ouer-kind verhouding.

Dit is egter ook baie belangrik om daarop te wys dat geen van die genoemde fundamentele regte absolute aanwending vind nie. Artikel 33(1) van die 1993 Grondwet en artikel 36(1) van die 1996 Grondwet bepaal dat regte wat onderskeidelik in hoofstuk 3 en 2 verskans is, beperk kan word deur algemene geldende reg, as só 'n beperking redelik is, regverdigbaar is in 'n oop en demokratiese samelewing gebaseer op vryheid en gelykheid, nie die wesenlike inhoud van die betrokke reg ontken nie en ook noodsaaklik is. Hieruit volg dit dus dat die algemene geldende reg die grondwetlike aanspraak van ' $n$ minderjarige kind in die Suid-Afrikaanse gemeenskap kan beperk.

89 A 30(3) van die 1993 Grondwet en a 28(2) van die 1996 Grondwet stipuleer dat die beste belang van die kind in alle omstandighede geld. Dit wil sê nie net waar die kind fisies sorgbehoewend is nie, maar ook waar sy emosioneel sorgbehoewend is.

90 Die bepalings van hierdie artikels is in lyn met die bewoording van a 6(4) van die Wet op Egskeiding 70 van 1979. ' $n$ Moontlike oplossing vir ' $n$ minderjarige om hierdie reg uit te oefen, is deur vir haar 'n curator ad litem aan te stel wat namens haar kan verskyn in so 'n geding wat handel oor konflik in die besluitnemingsproses binne die gesin.

91 Die volgende faktore moet in gedagte gehou word, sou 'n reg beperk word: A 36(1)(a-e) van die 1996 Grondwet bepaal:

die aard van die reg, die belangrikheid van die doel vand ie beperking, die aard en omvang van die beperking, die verband tussen die beperking en die doel daarvan en ' $n$ minder beperkte wyse om die doel te bereik. Tog bepaal a 36(2): 
Dit is duidelik dat artikels 30 en 28 van die Grondwette 'n duidelike verpligting plaas op die Suid-Afrikaanse gemeenskap om van kinderbeskerming en versorging 'n nasionale prioriteit te maak. Die Minister van Welsyn en Bevolkingsontwikkeling het dit in 1996 duidelik gestel dat die Suid-Afrikaanse regering daartoe verbind is om 'n gemeenskap daar te stel waarin die Suid-Afrikaanse kind tot haar volle potensiaal kan ontwikkel. ${ }^{92}$ Daarom het die Suid-Afrikaanse regering die Nasionale Plan van Aksie vir kinders (NPA) aangeneem. Die oogmerke van die NPA kan soos volg verduidelik word:

The objectives of this Plan include a review and adaptation of the global goals for child survival, protection and development, to publicise the goals and the work of the NPA and to mobilise popular support. The NPA also sets targets to improve the circumstances of the world's most vulnerable children by the turn of the century.

Die NPA gaan 'n nasionale kinderbeskermingstrategie gebruik om die kinders se posisie in die gemeenskap te verbeter. Die volgende elemente in die strategie kan uitgelig word. Eerstens beoog die NPA om alle beleidsbepalings, wetgewing en programme wat kinders as primêre onderbou het, te hersien. Tweedens beoog die NPA om voorkomingstrategieë en voorkomingsopvoeding en onderwysprogramme te ontwikkel en te implementeer. Derdens gaan die NPA 'n sentrale register en databasis (op nasionale en provinsiale vlak) daarstel om oortreders en hul oortredings teen kinders aan die gemeenskap voor the hou. ${ }^{94}$

Robinson klassifiseer die regte van kinders vervat in artikel 30 van die 1993 Grondwet as tweedegenerasie regte en verklaar dat daar kritiek teen die beklemtoning

Behalwe soos in subartikel (1) of in enige ander bepaling van die Grondwet bepaal, mag geen regsvoorskrif enige reg wat in die Hndves van Regte verskans is, beperk nie.

92 Fraser-Moleketi Keynote Address 3 (teks op lêer by outeur).

93 Fraser-Moleketi Keynote Address 3.

94 Fraser-Moleketi Keynote Address 4-5. Sien ook ibid 4 waar daar na 'n kategorie kinders verwys word wat deur die NPA se kinderbeskermingstrategie geraak sal word. Daar word na die kinders verwys as "children living in difficult circumstances." 
van sodanige regte uitgespreek kan en moet word. ${ }^{95}$ Twee van sy grootste kritiekpunte is dat dié regte die demografiese werklikhede van Suid-Afrika ontken en tweedens wyk dit wesentlik af van die Konvensie van die Regte van die Kind (1989) van die Verenigde Nasies. Robinson glo dat die nadeel van sodanige verskansing van tweedegenerasie regte getemper kan word deur die kind (beklee met fundamentele regte) in familieverband te sien en nie buite die gesinsverband nie.

\subsection{Gevolgtrekking}

Die bepalings van die 1993 Grondwet en die 1996 Grondwet ten aansien van die kind in 'n multikulturele gemeenskap het ingrypende veranderinge in die ouer-kind verhouding teweeggebring. Die staat word as derde party in die ouer-kind verhouding ingetrek, deurdat dié party moet sorg dra dat die grondwetlik beskermde fundamentele regte aan die kind gewaarborg en beskikbaar gestel word.

Die grondwetlike bepalings bring ook 'n klemverskuiwing in die ouer-kind verhouding mee.

Die klem verskuif vanaf die ouers se regte en verpligtinge na die aanspraakregte van die kind (wat deur die staat in die ouer-kind verhouding gewaarborg word). Die kind kan die regte teenoor die staat en haar ouers afdwing. Die maatstaf waarmee beoordeel word of die kind op hierdie aanspraakregte geregtig is, is die beste belang van die kind. Artikels 34 en 28(1)(h) van die 1996 Grondwet spreek die locus standi-probleem, wat die kind mag ervaar, aan. Sou die kind die hooggeregshof as gemeenregtelike oppervoog nader om die aanspraakregte af te dwing óf om 'n balans daar te stel in die besluitnemingsproses binne die ouer-kind verhouding, moet die staat aan die kind die nodige regsverteenwoordiging verskaf.

Dit is duidelik dat die daarstel van die NPA en die nasionale kinderbeskermingstrategie deur die Suid-Afrikaanse regering van die volgende

95 Robinson Beskerming van Kinders 1-3. Sien ook, in die algemeen, De Vos 1995 SAPR/PL 233259; Du Plessis en Gouws 1996 SAPR/PL 472-489 484-485; Robinson 1996 Woord en Daad 910 waar hy opnuut dié regte klassifiseer as tweede generasie regte en op moontlike probleme dui wat ervaar kan 
word deur die staat wanneer dit geïmplementeer en/of afgedwing moet word. 
spreek:

The South African Government has the challenging task to facilitate a positive change in the lives of children.

Die persoonlikheidsontwikkeling van die kind kan dit ook gebiedend maak dat in bepaalde gevalle (reeds voor die intrede van privaatregtelike meerderjarigheid), 'n selfstandige besluitnemingskompetensie rakende die uitvoering van haar fundamentele regte aan haar verleen word. Die Suid-Afrikaanse regsgemeenskap moet dus besef dat daar oorweging geskenk sal moet word aan die vlak van die kind se persoonlikheidsontwikkeling en die vraag in hoe 'n mate die betrokke geval die persoonlikheid van die kind raak, eerder as aan die kind se toepaslike privaatregtelike minderjarigheidsouderdom.

\section{Samevatting}

Die Suid-Afrikaanse reg se fokuspunt ten aansien van die ouer-kind verhouding sal ingrypend moet verander, veral in die lig van die gees en strekking van die bepalings van die Grondwette wat beskerming aan die beste belang van die kind verleen. Die ouer-kind verhouding moet nie meer aan die hand van reëls van gesag omlyn word nie, maar eerder deur die klem te plaas op die bevordering van die kind se belange. Die beste belang van die kind moet dus die sluitsteen in alle regsprosesse wees.

Dit impliseer verder dat die Suid-Afrikaanse familiereg se benadering tot die balansering van die besluitnemingsproses in die ouer-kind verhouding ook moet verander. Artikels 30 van die 1993 Grondwet en 28 van die 1996 Grondwet het nie

96 Hy maak nie konsekwent gebruik van die begrippe familie en/of gesin nie. Dit is nie duidelik watter inhoud hy aan dié twee berippe gee nie. Sien ook Robinson Beskerming van Kinders 11 vir sy interpretasie van die staat se toesighoudende rol soos vervat in a 30 van die 1993 Grondwet.

97 Fraser-Moleketi Keynote Address 6. Hierdie benadering vind aansluiting by die bepalings van a 7 van die 1996 Grondwet.

98 Regshervormers sal duidelikheid moet verleen oor die verskil tussen die publiekregtelike en die privaatregtelike meerderjarigheidsouderdomme wat in die Suid-Afrikaanse familiereg aanwesig is. $\mathrm{Na}$ die aanneem van die grondwette beweeg die ouer-kind verhouding nie meer in 'n geïsoleerde 
privaatreg paradigma nie, maar eerder in 'n publiekreg paradigma met 'n privaatreg onderbou. 
net die sorgbehoewende situasie van 'n mishandelde en seksueel gemolesteerde kind in gedagte nie, maar ook die konfliksituasie wat mag ontstaan waar 'n sorgbehoewende kind ernstige emosionele en geestelike/psigiese benadeling in die ouer-kind verhouding ervaar. Dié uitgangspunt word onderskryf deur die NPA se kategorisering van "... children living in difficult circumstances".

Die begrip ouerlike sorg in artikel 30 van die 1993 Grondwet en die toeligting daarvan in artikel 28(1)(b) van die 1996 Grondwet, moet nie as 'n alternatief vir ouerlike gesag gesien word nie. Dit dui eerder op die bewaringsplig wat ouers teenoor hulle kinders het. Dit moet eerder deur die wetgewer oorweeg word om 'n begrip soos ouerlike verantwoordelikheid as alternatief vir ouerlike gesag te gebruik.

McCall v McCall is 'n voorbeeld van die sukses wat behaal kan word wanneer die hof aan die hand van gedefinieerde faktore, oorwegings en aanbevelings van die gesinsadvokaat ' $n$ positiewe houding handhaaf ten aansien van judisiële inmenging in die ouer-kind verhouding. Die Suid-Afrikaanse regbank moet nie alleen konsentreer op die minderjarige se ouderdom wanneer ' $n$ balansering in die besluitnemingsproses binne die ouer-kind verhouding gevind word nie, maar daar moet gekyk word na die intellektuele en emosionele volwassenheid waaroor die kind beskik ten einde besluite te neem en voorkeure te hê aangaande haar eie welvaart en welsyn. Dit is duidelik dat die ouer se regte en verantwoordelikhede in die Suid-Afrikaanse reg beperk moet word deur die selfbestemmingsaanspraak van die kind.

Die uitoefening van ouerlike verantwoordelikheid in die Suid-Afrikaanse familiereg is onder die toesig van die staat geplaas deur die fundamentele regtebepalings van die grondwette. Dit kan kwalik anders wanneer die kind 'n draer is van fundamentele regte wat deur die uitoefening van ouerlike regte en verantwoordelikhede of andersins geskend kan word. Die staat het ook sy legitieme belang in die behoorlike opvoeding van kinders deur die daarstel van die NPA erken en verwoord. Langs dié weg moet daar deur die Suid-Afrikaanse wetgewer grondwetlik verantwoordbare meganismes en remedies ter beskerming van die kind oor 'n breë front gestel word. 
Dit is nodig om ten slotte op die volgende woorde van Nhlapo, ten aansien van die toekoms van die Suid-Afrikaanse familiereg te let:

(T)he family law of a new South Africa will have to take on a 'mobilization' role to some extent. This is forced upon it by the nature of the job that needs to be done: that job is to breathe new life into personal relationships in the home according to what, for many, will be the relatively novel concepts of equality, liberty and democracy. In other words a new family law must be compatible with a democratic constitution and a bill of rights.

Dit beteken dus dat die ouer-kind verhouding die grondwette se norme moet weerspieël, aangesien beide ouers en kinders oor afdwingbare grondwetlike regte in ' $\mathrm{n}$ oop en demokratiese multi-kulturele gemeenskap beskik. Hierdie verhouding moet 'n demokratiese verhouding wees, gekenmerk deur die feit dat elke individu se menswaardigheid erken en gerespekteer word, en dat daar binne hierdie verhouding geen sprake is van enige geslags- of rassediskriminasie nie. 
99 McCall v McCall 19943 SA 201 (K).

100 Nhlapo Future of Family Law 1014. 


\section{BIBLIOGRAFIE}

\section{Boeke}

B

Barnard, Cronjé en Olivier Persone- en Familiereg

Barnard AH, Cronjé DSP en Olivier PJJ Die Suid-Afrikaanse Persone- en Familiereg (Butterworths Durban 1986)

Bennet Human Rights

Bennet TW Human Rights and African Customary Law (Juta Kaapstad 1995)

Boberg Persons and the Family

Boberg PQR The Law of Persons and the Family (Juta Kaapstad 1977)

K

Kimathi Marraige and Family

Kimathi G Your Marriage and Family (IRS-Studiestuk no 58 Potchefstroom 1994)

M

Maré Gesinspolitiek

Maré C Gesinspolitiek en die Ouer-Kind Verhouding (LL M-Verhandeling PU vir CHO 1996)

McQuoid-Mason Street Law

McQuoid-Mason D Street Law: Practical Law of South African Students Vol 4 (Juta Kaapstad 1990)

$\mathbf{N}$

Nhlapo Future of Family Law

Nhlapo RT "The Future of Family Law and the Law of Persons in South Africa: Is 273/279 
Modernization Compatible with Africanization?" in Van Aswegen A (red) Die Toekoms van die Suid-Afrikaanse Privaatreg (Univeriteit van Suid-Afrika Pretoria 1994) 10-25 
0

Olivier Indigenous law

Olivier NJJ ea Indigenous Law (Durban 1994)

Olmesdahl Family Life

Olmesdahl MCJ "The Regulation of Family Life" in Rycroft A (red) Race and the Law in South Africa (Juta Kaapstad 1987) 93-106

R

Robinson Beskerming van Kinders

Robinson JA Die Beskerming van Kinders in 'n Menseregteakte in Suid-Afrika: QUO OPERTET NOS VADERE? (Sentrale Publikasies Potchefstroom 1993)

\section{S}

Spiro Parent and Child Spiro E Law of Parent and Child 4e uitg (Juta Kaapstad 1985)

V

Van der Vyver en Joubert Persone- en Familiereg

Van der Vyver JD en Joubert DJ Persone- en Familiereg 3e uitg (Juta Kaapstad 1985)

Visser en Potgieter Family Law

Visser PJ en Potgieter JM Family Law: Cases and Materials (Juta Kenwyn 1994)

Visser en Potgieter Familiereg

Visser PJ en Potgieter JM Inleiding tot die Familiereg (Juta Kenwyn 1994) 


\section{Tydskrifartikels}

Bekker JC "How Compatible is African Customary Law with Human Rights? Some Preliminary Observations" 1994 THRHR 440-447

Burman S "Illegitimacy and the African Family in a Changing South Africa" 1991 AJ 3651

Costa A "Polygamy, other Personal Relationships and the Constitution" 1994 De Rebus 914-918

De Koker JY "Die Status van die Inheemse reg in die Suid-Afrikaanse Regsisteem na 27 April 1994" 1996 TRW 112-122

De Vos $\mathrm{P}$ "Same-sex Marriage, the rights to equality and the South African Constitution" 1996 SAPR/PL 355-382

De Vos $\mathrm{P}$ "The Economic and Sosial Rights of Children and South Africa's Transitional Constitution" 1995 SAPR/PL 233-259

Dlamini CRM "The Role of Customary Law inMeeting Social Needs" 1991 AJ 71-85

Du Plessis LM en Gouws A "The Gender Implications of the Final Constitution (with particular reference to the bill of rights)" 1996 SAPR/PL 472-489

Govender K "Fraser v Children's Court, Pretoria North and Others" 1997 Human Rights and Constitutional Law Journal of Southern Africa 28-29

Heaton J "Some General Remarks on the Concept 'Best Interest of the Child' 1990 THRHR 95-99

Kerr AJ "Customary Law, Fundamental Rights, and the Constitution" 1994 SALJ 720Nhlapo 
RT "The African Family and Women's Rights: Friends or Foes?" 1991 AJ 135-146 
Robinson JA "Kinderregte in die Nuwe Grondwet" 1996 Woord en Daad 9-10

Sonnekus JC "Die Onwelkome Vryer en die Regsweg van die Onstoke Vader" 1992 THRHR 649-658

Wolhuter L "Horizontality in the Interim and Final Constitutions" 1996 SAPR/PL 512-527

\section{Hofsake}

$B$ v S 19932 SA $211(\mathrm{~W})$

Calitz v Calitz 1939 AD 56

Coetzee $v$ Meintjies 19761 SA 257 (T)

Deijl v Deijl 19664 SA 260 (R)

Ex parte Kedar and Another 19931 SA 242 (W)

G v Superintendent, Groote Schuur Hospital, and Others 19922 SA 594 (OK)

Gordon v Barnard 19771 SA $887(\mathrm{~K})$

H v I 19853 SA 237 (K)

Kastan $v$ Kastan 19853 SA $235(\mathrm{~K})$

L v H 19902 SA 594 (OK)

McCall v McCall 19943 SA 201 (K)

Meyer v Van Niekerk 19761 SA 252 (T)

Msweli v Msweli 1985-6 AC (N-E)

S v S 19932 SA 200 (W)

Van Erk v Holmer 19922 SA 636 (W)

Van Rooyen v Van Rooyen 19942 SA 325 (W) 


\section{Wetgewing}

Huwelikswet 25 van 1961

KwaZulu-Natal Wetboek 16 van 1985

Prok R151 van 1987

Wet op Bemiddeling in Sekere Egskeidingsaangeleenthede 24 van 1987

Wet op die Meerderjarigheidsouderdom 57 van 1972

Wet op Egskeiding 70 van 1979

Wet op Huweliksaangeleenthede 37 van 1953

Wet op Keuse oor die beëindiging van Swangerskap 92 van 1996

Wet op Kindersorg 74 van 1983

Wet op Voogdy 192 van 1993

Wet op Voorkoming van Gesinsgeweld 133 van 1993

Wet op Vrugafdrywing en Sterilisasie 2 van 1975

Wysigingswet op Bewysreg 45 van 1988

Wysigingswet op Kindersorg 86 van 1991

\section{Bydraes by Konferensies}

Fraser Moleketi G Keynote Address

Fraser Moleketi G "Keynote Address on Child Abuse as a Priority Crime" lesing gelewer by die Werkswinkel oor Child Abuse, 17-18 Oktober 1996 Mmabatho 1-6 